\author{
A. Świerczyńska* \\ Gdańsk University of Technology, Faculty of Mechanical Engineering, 80-233 Gdańsk, \\ Narutowicza 11/12, Poland \\ *aleswier@pg.edu.pl
}

\title{
EFFECT OF STORAGE CONDITIONS OF RUTILE FLUX CORED WELDING WIRES ON PROPERTIES OF WELDS
}

\begin{abstract}
The influence of storage locations of two grades of rutile flux cored welding wires on their surface condition and the strength of the welds made with them were studied. Wires were stored in real urban conditions (Gdańsk and Katowice) for 1 month, simultaneously recording changes in conditions: temperature and relative humidity of the environment. Visual tests of wires in the delivered and stored condition as well as visual and tensile strength tests of welds made with them were carried out. It was found that the surface of the wires underwent more intense degradation (atmospheric corrosion) during storage in Katowice than in Gdańsk. Significant difference in tensile strength was observed only for padding welds made using Gdańsk stored wires. The lowest recorded tensile strength value was not lower than the standard requirements for the wires.
\end{abstract}

Keywords: welding, FCAW, storage conditions, tensile strength, atmospheric corrosion

\section{INTRODUCTION}

Arc welding using FCAW (Flux Cored Arc Welding) is a commonly used alternative to GMAW (Gas Metal Arc Welding) due to higher welding efficiency, penetration depth, better arc stability and relative ease of welding [1-4]. The area of its application includes, in particular, shipbuilding, construction and machine industry as well as regeneration of machine elements, technical devices, manufacturing and modification of surface layers [5-8]. A specific area of application includes the use of flux cored wires for underwater welding [9-11]. Consumables for welding by this process include: basic cored wires, rutile cored wires, self-shielded wires and shielding gases such as $\mathrm{CO}_{2}$ and $\mathrm{Ar}+\mathrm{CO}_{2}$ mixture. Appropriate selection of process parameters and filler materials enables the creation of a continuous, metallic weld without welding defects disqualifying the welded joint from operation [12-17]. For the proper quality of the process, it is necessary to maintain a technological regime in the scope of storage of welding consumables. Flux cored wire manufacturers make recommendations regarding ranges of humidity, temperature and time of storage of opened packages of wire. The list of parameter values describing the conditions that should be kept in the warehouse of consumables is presented in Table 1. Keeping these conditions in the warehouse guarantees that the declared properties will be maintained. In a situation where the wires are subjected to conditions exceeding the boundary conditions, their degradation may occur [18]. One of the main factors that is considered to degrade the properties of wires and welded joints is the presence of hydrogen, which, when exceeding the low-hydrogen level, 
can contribute to the formation of cold cracks, porosity or hydrogen embrittlement in both ferritic-pearlitic steels and high-alloy steels [19-22]. The authors primarily pay attention to the consequences of incorrect storage of welding wires manifested as weld porosity and an increased amount of hydrogen in joints [23,24].

Table 1. Manufacturers recommendations for flux cored wires storage conditions

\begin{tabular}{|c|c|c|}
\hline Manufacturer & Max temperature & Max relative humidity \\
\hline \multirow{2}{*}{ LINCOLN ELECTRIC } & $17 \div 27^{\circ} \mathrm{C}$ & $60 \%$ \\
\hline & $27 \div 37^{\circ} \mathrm{C}$ & $50 \%$ \\
\hline TECHNI-TOOL & $\max 22^{\circ} \mathrm{C}$ & $80 \%$ \\
\hline NST & $\max 30^{\circ} \mathrm{C}$ & $80 \%$ \\
\hline \multirow{2}{*}{$\begin{array}{l}\text { WELDING ALLOYS } \\
\text { GROUP }\end{array}$} & $15 \div 25^{\circ} \mathrm{C}$ & $60 \%$ \\
\hline & $25 \div 35^{\circ} \mathrm{C}$ & $50 \%$ \\
\hline SANDVIK & $10 \div 30^{\circ} \mathrm{C}$ & $70 \%$ \\
\hline \multirow{3}{*}{ ESAB } & $5 \div 15^{\circ} \mathrm{C}$ & $60 \%$ \\
\hline & $5 \div 25^{\circ} \mathrm{C}$ & $50 \%$ \\
\hline & higher than $25^{\circ} \mathrm{C}$ & $40 \%$ \\
\hline ELGA & $10 \div 30^{\circ} \mathrm{C}$ & $80 \%$ \\
\hline INDIUM CORPORATION & $\max 40^{\circ} \mathrm{C}$ & $80 \%$ \\
\hline HYUNDAI WELDING & $20 \div 40^{\circ} \mathrm{C}$ & $50 \div 70 \%$ \\
\hline KOBELCO & $10 \div 30^{\circ} \mathrm{C}$ & $80 \%$ \\
\hline KESTER & $10 \div 40^{\circ} \mathrm{C}$ & - \\
\hline
\end{tabular}

The basic description of the interaction of hydrogen in steel in accordance with the HELP and HEDE mechanisms is the reduction of forces needed to propagate the crack in the specimen. The hydrogen present in the material may be trapped or diffusible. Until hydrogen is trapped in irreversible or deep traps (solutes, precipitates, inclusions) it does not pose a threat to the material. However, the influence of hydrogen released during operation from reversible or shallow traps and the influence of diffusible hydrogen occurring in the material, e.g. during welding, is a highly degrading. It is important to control the diffusible hydrogen amount within the microstructure in order to ensure its resistance to embrittlement $[25,26]$. In the case of welding, one of the basic ways to implement such control is to assess the state of welding consumables and their impact on the level of diffusible hydrogen. The presence of hydrogen can be macroscopically observed through a decrease in plasticity of metal $[27,28]$.

Atmospheric corrosion is one of the common processes of destruction of metal materials and causes great economic losses [29]. The mechanism of this corrosion has been described in the literature, among others in terms of metallurgy, effect of environment and properties of layers [30,31]. There are many methods to prevent corrosion, the most important of which are the use of anti-corrosion coatings, cathodic and anodic protection [32-35]. Corrosion intensity of welded joints depends, among others, on their operating environment. The urban environment is significantly different from the rural environment. Research indicates that 
inside and around cities, the air temperature is higher than in nearby rural areas - this phenomenon is known as urban heat island effect [36,37]. This is due to the large amount of artificial surfaces that absorb radiation and the decrease in the surface of water evaporation from the soil, which effectively lowers the air temperature. As a result of human activity, the conditions for storage and use of materials also change. An additional factor having an impact on the environment is the degree of industrialization of urban areas and natural conditions resulting from the geographical location [38]. Such a large number of variables suggests the need to compare the impact of various environments of different geographical - anthropogenic nature on welding consumables that are considered sensitive to adverse external factors.

Objective of this study is to verify the influence of the real storage environment on the surface condition of rutile flux cored welding wires and appearance and strength properties of welds made with them.

\section{EXPERIMENTAL}

Two grades of rutile flux cored wires T 462 P M21 2 H5 class were used for the study. Both wires were copper coated, seamless, low hydrogen wires with a diameter of $1.2 \mathrm{~mm}$. They were placed in open packaging in real conditions (without the possibility of direct contact with water) in two Central European cities that differ significantly in geographical location and degree of industrialization - in Gdańsk $\left(54^{\circ} 20^{\prime} 51^{\prime \prime} \mathrm{N} 18^{\circ} 38^{\prime} 43^{\prime \prime} \mathrm{E}\right)$ - a maritime economy center with a large commercial port, absolute height up to $180.1 \mathrm{~m}$ a.s.l. and in Katowice $\left(50^{\circ} 15^{\prime} 51^{\prime \prime} \mathrm{N} 19^{\circ} 01^{\prime} 25^{\prime \prime} \mathrm{E}\right)$ - the main city in the Upper Silesian Industrial Region, absolute height 245-357 $\mathrm{m}$ a.s.l. Throughout the storage of wire spools (1 month: from February 15 to March 15), temperature and relative humidity were recorded in situ using a recorder Termioplus with SHT15 sensor (temperature recording with a resolution of $0.1^{\circ} \mathrm{C}$, humidity registration with a resolution of $0.1 \% \mathrm{RH})$.

After 1 month, the wires were visually examined. Then padding welds were made on samples of S355J2 steel coupons with dimensions of $10 \times 25 \times 180 \mathrm{~mm}$ and chemical composition presented in Table 2. Welding was performed on the robotized station ABB IRB 2400 to ensure a constant welding speed. Mixture $\mathrm{Ar}+18 \% \mathrm{CO}_{2}$ (PN-EN ISO 14175: M21) was used as shielding gas. Welding was carried out at an average welding current of $210 \mathrm{~A}$, wire feed speed $9 \mathrm{~m} / \mathrm{min}$, arc voltage $25 \mathrm{~V}$, welding speed $30 \mathrm{~mm} / \mathrm{min}$, stick out length 20 $\mathrm{mm}$ and shielding gas flow rate $17 \mathrm{l} / \mathrm{min}$.

Table 2. Chemical composition in percentage by weight (wt. \%) of the S355J2 steel according to PN-EN 10025-2:2004 standard

\begin{tabular}{cccccc}
\hline $\mathrm{C}$ & $\mathrm{Si}$ & $\mathrm{Mn}$ & $\mathrm{P}$ & $\mathrm{S}$ & $\mathrm{Cu}$ \\
$\max$ & $\max$ & $\max$ & $\max$ & $\max$ & $\max$ \\
\hline 0.20 & 0.55 & 1.60 & 0.025 & 0.025 & 0.55 \\
\hline
\end{tabular}

Specimens after welding were cooled and stored in liquid nitrogen to inhibit hydrogen diffusion. Just before the tensile test, the specimens were brought back to ambient temperature. The tensile test of the padding welds was carried out on a Hung Ta HT-2401 testing machine with deformation speed $2 \mathrm{~mm} / \mathrm{min}$. The measurements of the surface area of the weld fractures were made in the image analysis program. 


\section{RESULTS AND DISCUSSION}

The process of temperature and relative humidity changes at both locations is shown in Figures 1 and 2. Table 3 presents the values of the coefficients describing the variability of recorded environmental parameters over a period of 1 month. In addition to the standard measures of central tendency and dispersion: maximum, minimum, range, mean, and standard deviation, the coefficient of variation (V) was also calculated according to the formula [39]:

$$
V=\frac{S}{X} \times 100 \%
$$

where:

$\mathrm{S}$ - standard deviation, $\mathrm{X}$ - mean value.

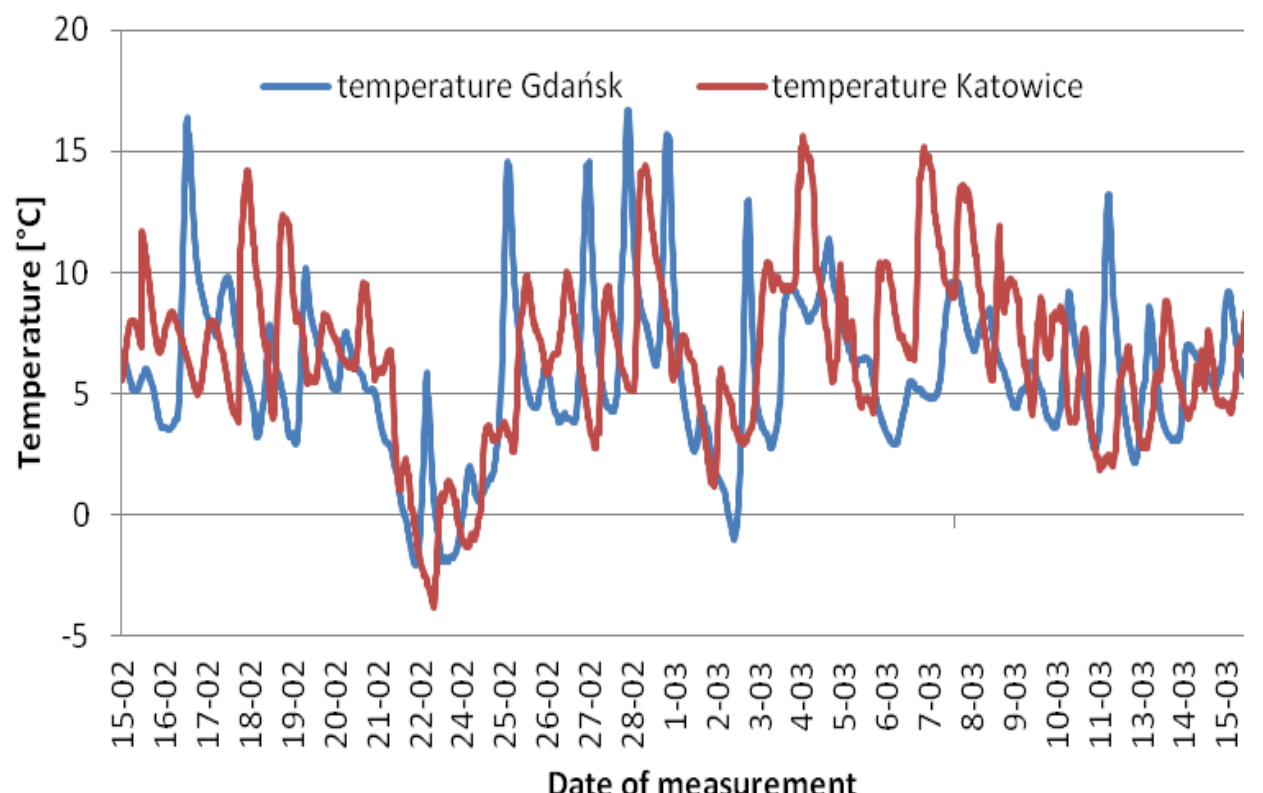

Fig. 1. Ambient temperature changes during wires storage

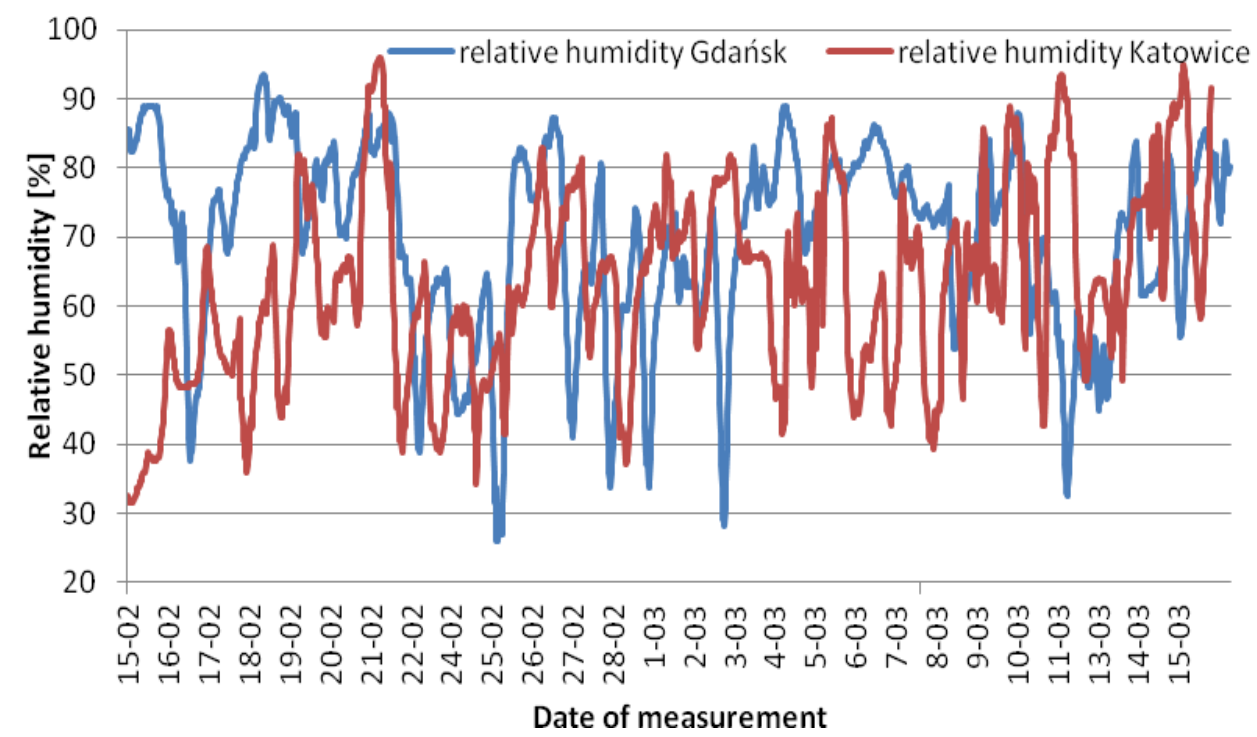

Fig. 2. Ambient relative humidity changes during wires storage 
Katowice, despite the lower maximum and minimum temperature value, was characterized by a higher mean air temperature. However, a higher mean relative humidity value of almost $70 \%$ characterized Gdańsk. Considering only the mean values of the measured factors, it can be concluded that both locations met the conditions that are considered by the manufacturers of consumables as safe. However, as shown in Table 3, there were periodic changes in conditions that could accelerate the degradation of flux cored wires.

Table 3. Coefficients describing changes in storage conditions

\begin{tabular}{c|c|c|c|c|}
\hline \multirow{2}{*}{ Condition/localisation } & \multicolumn{2}{|c|}{ Temperature, ${ }^{\circ} \mathrm{C}$} & \multicolumn{2}{c|}{ Relative humidity, \% } \\
\cline { 2 - 5 } & Gdańsk & Katowice & Gdańsk & Katowice \\
\hline Max & 16.7 & 15.6 & 93.6 & 95.8 \\
\hline Min & -2.1 & -3.8 & 25.9 & 31.5 \\
\hline Range & 18.8 & 19.4 & 67.7 & 64.3 \\
\hline Mean & 5.8 & 6.7 & 69.9 & 63.0 \\
\hline Standard deviation & 3.2 & 3.4 & 13.8 & 13.9 \\
\hline $\begin{array}{c}\text { Coefficient of } \\
\text { variation }\end{array}$ & 55.4 & 51.8 & 19.7 & 22.1 \\
\hline
\end{tabular}

The tested wires were subjected to visual examination in the delivery condition in order to assess the condition of the surface not exposed to the environment. Both wires have an smooth, shiny, copper plated surface and their arrangement on the spools is regular (Fig. 3). No contaminations or dirt were found on the surface of the wires.

a)

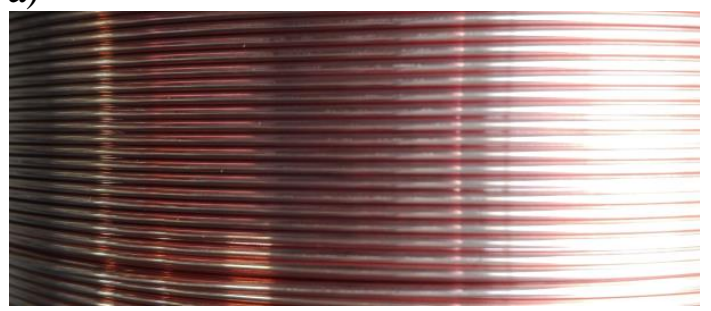

b)

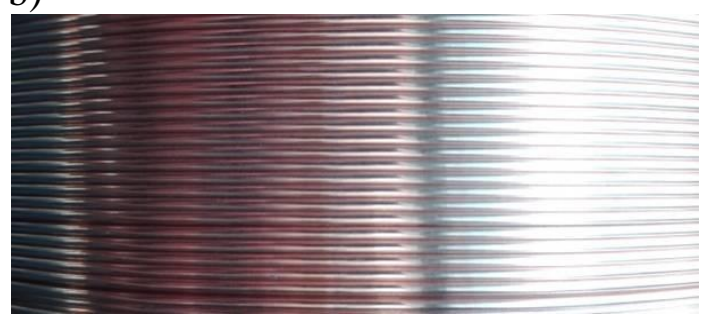

Fig. 3. Surface of flux cored wires in delivery conditions; a) wire $A$, b) wire $B$

After 1 month of storage the wires were visually examined to assess the degree of degradation of their surface. Fig. 4 shows photographs of the surface of the wires after storage. There were no corrosive changes on the surface of the A wire stored for 1 month in Gdańsk (Fig. 4a). The storage of A wire in Katowice caused the appearance of numerous corrosion centers on the entire surface of the wire. Corrosion unchanged areas still had a metallic sheen (Fig. 4c). The surface of the B wire located in Gdańsk showed slight point corrosion changes after 1 month (Fig. 4b). Simultaneous storage of this type of wire in Upper Silesia caused the appearance of even corrosion on the entire surface, but the thickness of the corrosion layer was not significant (Fig. 4d). The observed changes are the result of atmospheric corrosion, the mechanism of which is the interaction of a thin layer of salt and other components dissolved in water on the metal surface [40]. 
a)

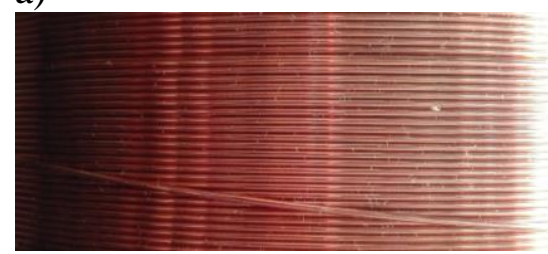

c)

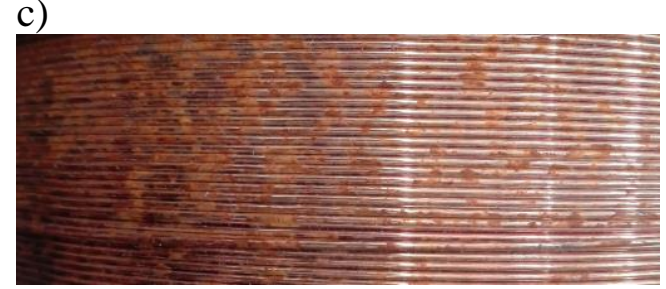

b)

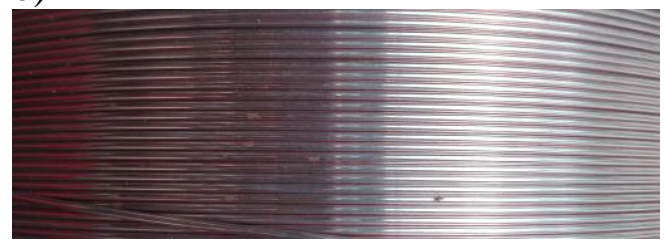

d)

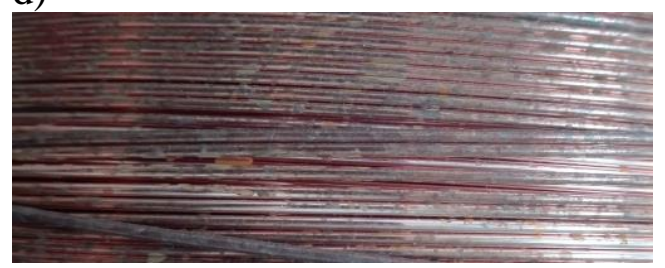

Fig. 4. Surface of flux cored wires after 1 month storage: a) Gdańsk - wire A; b) Gdańsk - wire B; c) Katowice - wire A; d) Katowice - wire B

In order to check the influence of the condition of the wire after storage on the quality of the weld metal, welding process was carried out. Obtained specimens were subjected to visual tests and to static tensile tests. Three tensile tests were carried out for each combination: location - wire. Fig. 5 shows a view of the exemplary specimens before and after tensile test. The padding welds are even, symmetrical with a smooth face. A few small spatters occur near the welds. On the face of welds made with stored wires small pores and a larger number of spatters were found, especially during striking of the welding arc (Fig. 5b).

a)

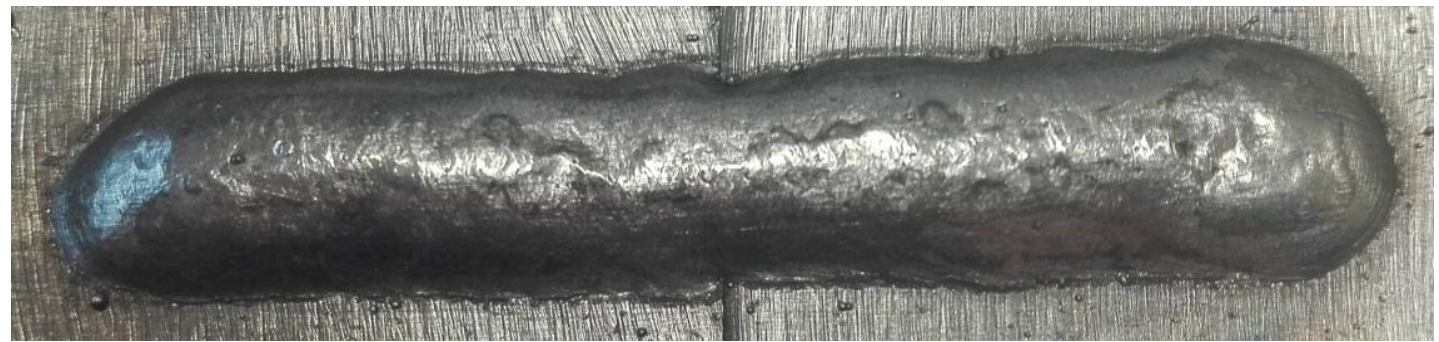

b)

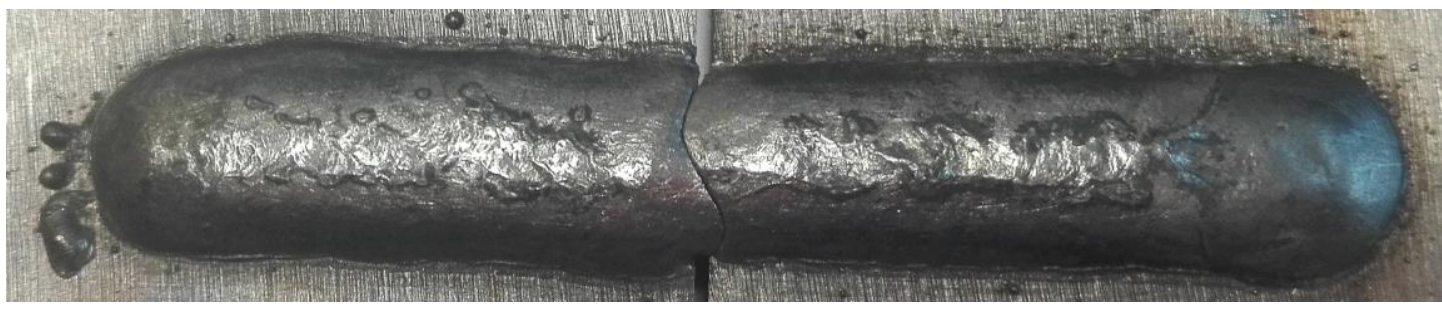

Fig. 5. Face of welds made on steel coupons; a) padding weld made with $B$ wire in delivery condition before tensile test; b) padding weld made with A wire storaged for 1 month in Gdańsk after the tensile test

During the static tensile test, the value of the maximum force was recorded, which was referred to the surface area of the fracture, obtaining the value of the tensile strength $\mathrm{Rm}$. Fractures of specimens made with wires in delivery condition and degraded during storage are shown in Figures 6 and 7. 
a)

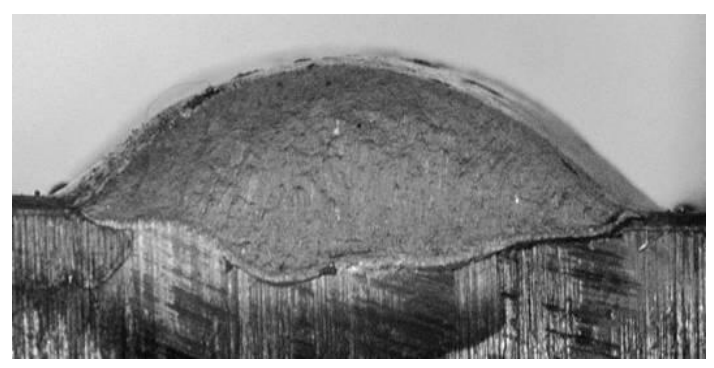

b)

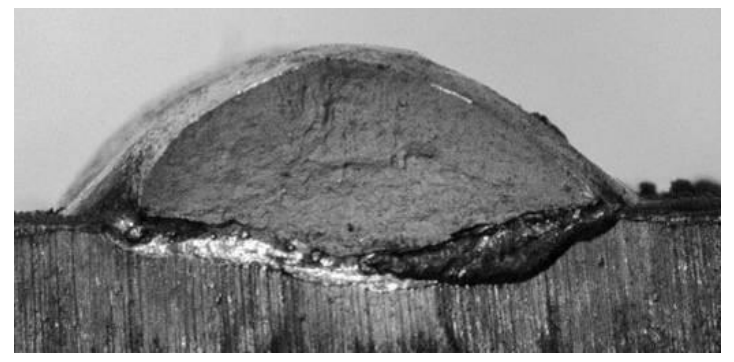

Fig. 6. Fractures of welds made with wires in delivery conditions; a) A wire; b) B wire

a)

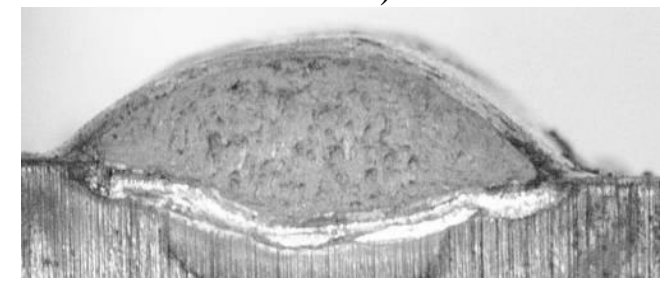

c)

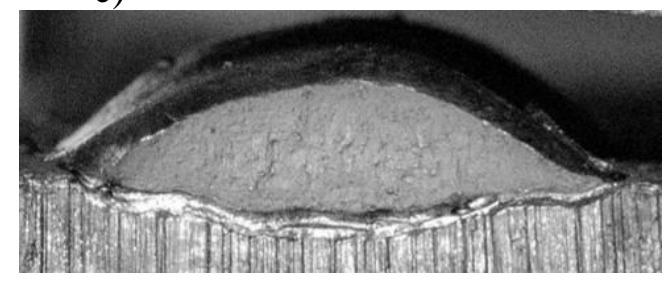

b)

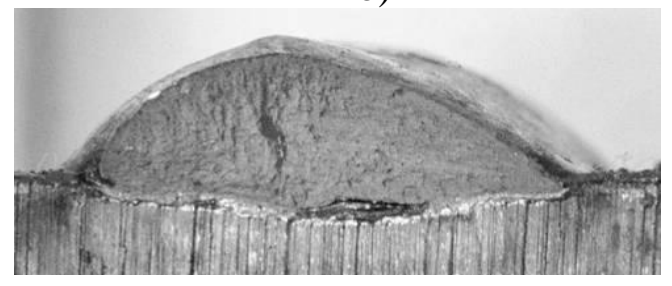

d)

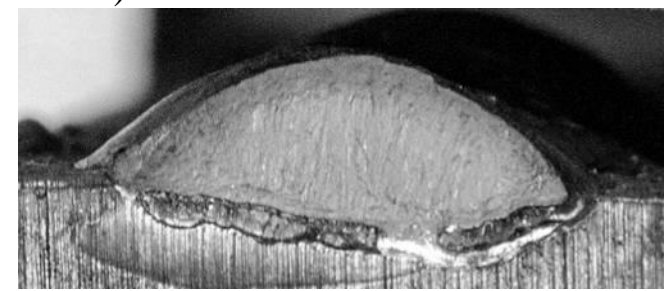

Fig. 7. Fractures of welds made with wires after 1 month storage; a) Gdańsk - A wire; b) Gdańsk - B wire; c) Katowice - A wire; d) Katowice - B wire

Fractures of the padding welds are characterized by fusion shape typical for a usage of $\mathrm{Ar}+\mathrm{CO}_{2}$ gas mixture. The base material was not preheated, and the welds were too short to observe deeper penetration - most of the surface of the fracture is weld reinforcement. This also means that the dilution of the base material and welding consumables was insignificant which makes it possible to compare the test results with the tensile strength of the weld metal declared by the manufacturers. The depth of penetration and the height of weld reinforcement for welding with A wire did not change significantly both for the wire stored in Katowice and Gdańsk. Specimens welded with B wire also show a similar structure between the delivery condition and the conditions after storage. Fractures are shiny and areas of breaks appear resulting from the heterogeneous, dendritic structure of the weld metal.

Figures 8 and 9 show the change in tensile strength of the welds made by the tested welding wires due to their storage (error bars indicate standard deviation). 


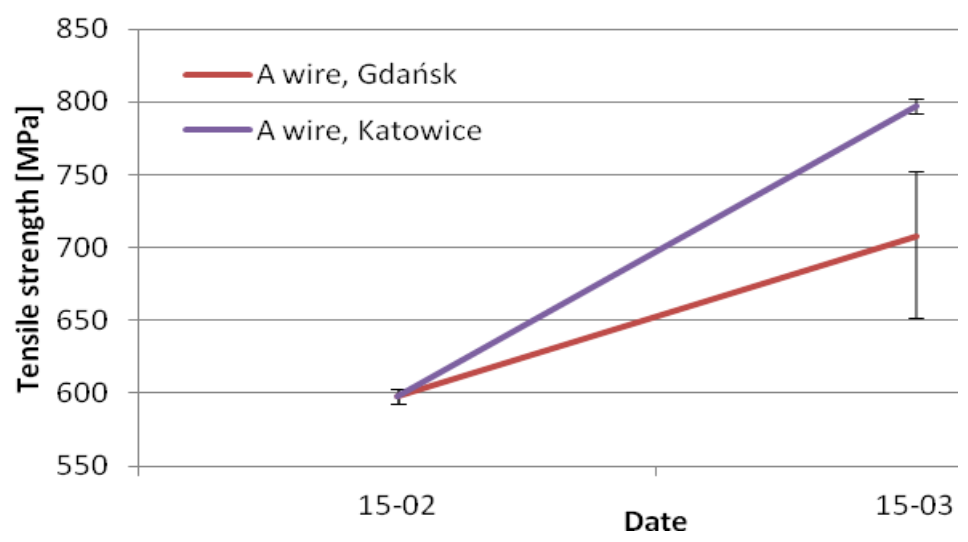

Fig. 8. Change in tensile strength of welds made with A wire caused by storage for 1 month

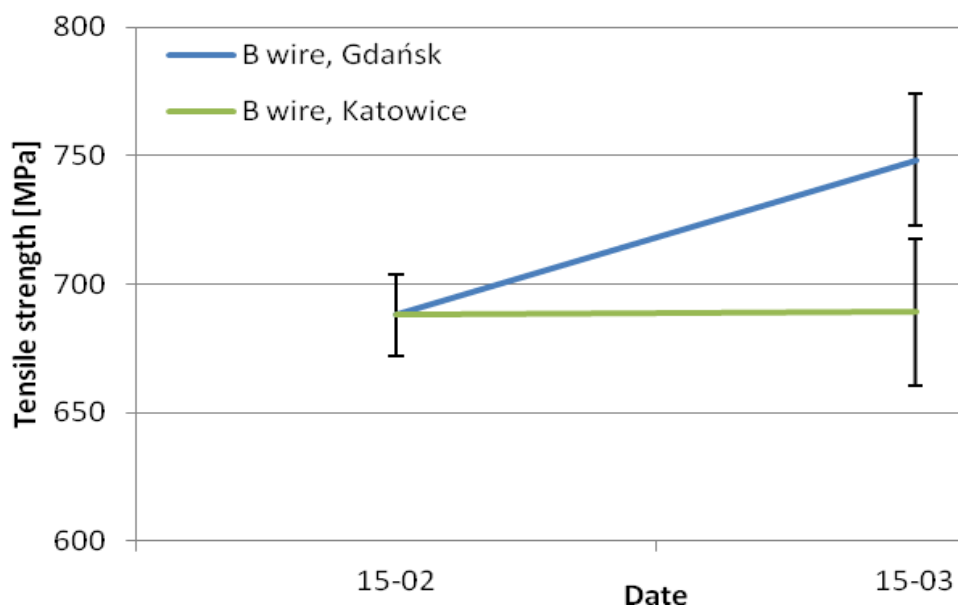

Fig. 9. Change in tensile strength of welds made with B wire caused by storage for 1 month

For both tested wires in the delivery condition, the padding welds were of higher strength than the minimum tensile strength of the weld metal required by the standard and were close to the typical value of strength declared by their manufacturers. For A wire in delivery condition, the average tensile strength was $598 \mathrm{MPa}$, while for B wire it was on average 688 $\mathrm{MPa}$. Storage of wires in real environments resulted in visible differences in tensile strength results determined after 1 month. The padding welds made with A wire, regardless of storage conditions, had higher strength than in the initial state, in the case of wire from Katowice it reached almost $800 \mathrm{MPa}$. The $\mathrm{B}$ wire, which in its initial state generates welds with higher strength than the A wire, is characterized by a smaller difference in the tensile strength value after 1 month of storage. Significant difference occur only for padding welds made using Gdańsk stored wire - mean tensile strength is about $50 \mathrm{MPa}$ higher. As it results from Fig. 9, the strength of welds made using wire stored in Katowice does not differ significantly from the initial strength. At the same time, even the lowest recorded value was not below the standard requirements for the wire.

By storing samples in liquid nitrogen until the tensile test was carried out, the cracking process could be modified by the presence of hydrogen in the deposited metal. Considering the observed wire degradation and the increase in weld tensile strength, it can be concluded that such a large increase in the strength of the welds cannot be unambiguously associated only with the action of hydrogen in the material - literature reports indicate that hydrogen has no effect on strength or can slightly decrease strength after hydrogenation. The material 
strengthening was influenced by the synergistic effect of hydrogen, surface precipitates and contaminations present on wires and the conditions of the thermal welding cycle.

\section{CONCLUSIONS}

The article concerns the study of the effects of storage of two grades of rutile flux cored wires in real conditions in two urban locations in Poland. Analysis of the results of research enabled the formulation of the following conclusions:

1. The differences in temperature and relative humidity changes from 15 February to 15 March in Gdańsk and Katowice were small and constitute only one of the factors affecting the degradation of the surface of wires and the change in the properties of padding welds made using them. Other factors, such as nitrogen, sulfur and carbon oxides could also have had a significant impact on the destruction of wires.

2. Regardless of the grade, the surface of the flux cored wires has been more intensively degraded due to storage in Katowice than in Gdańsk. Storage conditions and visual test results of the wire surface indicate that atmospheric corrosion is responsible for this process.

3. The synergistic effect of hydrogen, surface precipitations present on the wires and the conditions of the thermal welding cycle resulted in an increase in the tensile strength of the welding wires tested, with this phenomenon being more marked for wires stored in Gdańsk.

\section{ACKNOWLEDGEMENTS}

This work was supported by National Science Center (Grant Number: 2018/02/X/ST8/01627).

\section{REFERENCES}

1. Wang K., Lu Q., Yi Y., Yi J., Niu B., Jiang Z., Ma J.: Effects of welding heat input on microstructure and electrochemical behavior of flux-cored arc-welded Q690 HSLA steel. Advances in Materials Science and Engineering (2018) 7484025.

2. Ferreira M.L.R., Silva C.A.F.D., Pardal J.M., Tavares S.S.M.: Influence of shielding gas in FCAW process welding of UNS S31803 with E2209-T1/4 wire. Soldagem \& Inspeção 23(3) (2018) 309-325.

3. Rodrigues L.A., Borges D.J., Baia P.E., Freitas E.N., Braga E.M.: Welding procedures influence analysis on the residual stress distribution and distortion of stiffened panels welded via robotized FCAW. Thin-Walled Structures 141 (2019) 175-183.

4. Urbański T., Graczyk T., Taraska M., Iwańkowicz R.: Assessment of technological usefulness of panel production line in shipbuilding process. Polish Maritime Research 25(s1) (2018) 134-144.

5 . de Sousa Lins A., de Souza L.F.G., Fonseca M.C.: Characterization of mechanical properties and residual stress in API 5L X80 steel welded joints. Journal of Materials Engineering and Performance 27(1) (2018) 124-137.

6. Mu W., Li Y., Cai Y., Wang M., Hua X.: The cryogenic low-cycle fatigue performance of 9\% Ni steel joint made by flux cored arc welding. Materials Characterization 151 (2019) 27-37. 
7. Arun D., Ramkumar K.D., Vimala R.: Multi-pass arc welding techniques of $12 \mathrm{~mm}$ thick superduplex stainless steel. Journal of Materials Processing Technology 271 (2019) 126-143.

8 . Winczek J., Gucwa M., Mičian M., Koňár R., Parzych S.: The evaluation of the wear mechanism of high-carbon hardfacing layers. Archives of Metallurgy and Materials 64(3) (2019) 1111-1115.

9. Świerczyńska A., Fydrych D., Rogalski G.: Diffusible hydrogen management in underwater wet self-shielded flux cored arc welding. International Journal of Hydrogen Energy 42(38) (2017) 24532-24540.

10 . Yang Q., Han Y., Jia C., Wu J., Dong S., Wu C.: Impeding effect of bubbles on metal transfer in underwater wet FCAW. Journal of Manufacturing Processes 45 (2019) 682-689.

11. Wang J., Sun Q., Pan Z., Yang J., Feng J.: Effects of welding speed on bubble dynamics and process stability in mechanical constraint-assisted underwater wet welding of steel sheets. Journal of Materials Processing Technology 264 (2019) 389-401.

12. Guo N., Zhang X., Xu C., Chen H., Fu Y., Cheng Q.: Effect of parameters change on the weld appearance in stainless steel underwater wet welding with flux-cored wire. Metals 9(9) (2019) 951.

13. Pitrun M., Nolan D.U., Dunne D.: Diffusible hydrogen content in rutile flux-cored arc welds as a function of the welding parameters. Welding in the World 48(1-2) (2004) 2-13.

14. Schaupp T., Rhode M., Kannengiesser T.: Influence of welding parameters on diffusible hydrogen content in high-strength steel welds using modified spray arc process. Welding in the World 62(1) (2018) 9-18.

15. Bracarense A.Q., Souza R., Costa M.C.M., Faria P.E., Liu S.: Welding current effect on diffusible hydrogen content in flux cored arc weld metal. Journal of the Brazilian Society of Mechanical Sciences 24(4) (2002) 278-285.

16. Lee M., Cho K., Kim Y., Kang N.: Effect of martensite on cold cracking in 600-MPa grade fluxcored arc weld metals using the Y-groove test. Welding in the World 59(5) (2015) 647-654.

17. Alipooramirabad H., Paradowska A., Ghomashchi R., Reid M.: Investigating the effects of welding process on residual stresses, microstructure and mechanical properties in HSLA steel welds. Journal of Manufacturing Processes 28 (2017) 70-81.

18. Harwig D.D., Longenecker D.P., Cruz J.H.: Effects of welding parameters and electrode atmospheric exposure on the diffusible hydrogen content of gas shielded flux cored arc welds. Welding Journal 78 (1999) 314-321.

19. Fydrych D., Świerczyńska A., Tomków J.: Diffusible hydrogen control in flux cored arc welding process. Key Engineering Materials 597 (2014) 171-178.

20. Świerczyńska A., Fydrych D., Landowski M., Rogalski G., Łabanowski J.: Hydrogen embrittlement of X2CrNiMoCuN25-6-3 super duplex stainless steel welded joints under cathodic protection. Construction and Building Materials 238 (2020) 117697.

21. Świerczyńska A., Fydrych D., Łabanowski J.: The effect of welding conditions on diffusible hydrogen content in deposited metal. Solid State Phenomena 183 (2012) 193-200.

22 . Fydrych D., Łabanowski J.: An experimental study of high-hydrogen welding processes. Revista de Metalurgia 51(4) (2015) 10-3989.

23. Reisgen U., Willms K., Wieland S.: Influence of storage conditions on aluminum 4043A welding wires. Welding Journal 96(6) (2017) 220-227.

24. Tomków J., Fydrych D., Rogalski G., Labanowski J.: Effect of the welding environment and storage time of electrodes on the diffusible hydrogen content in deposited metal. Revista de Metalurgia 55 (2019) e140. 
25. Barrera O., Bombac D., Chen Y., Daff T.D., Galindo-Nava E., Gong P., Liverani C.: Understanding and mitigating hydrogen embrittlement of steels: a review of experimental, modelling and design progress from atomistic to continuum. Journal of Materials Science 53(9) (2018) 6251-6290.

26. Wasim M., Djukic M.B.: Hydrogen embrittlement of low carbon structural steel at macro-, microand nano-levels. International Journal of Hydrogen Energy (2020) (In press).

27 . Fu H., Wang W., Chen X., Pia G., Li J.: Fractal and multifractal analysis of fracture surfaces caused by hydrogen embrittlement in high-Mn twinning/transformation-induced plasticity steels. Applied Surface Science 470 (2019) 870-881.

28. Li L., Song B., Cai Z., Liu Z., Cui X.: Effect of vanadium content on hydrogen diffusion behaviors and hydrogen induced ductility loss of X80 pipeline steel. Materials Science and Engineering: A 742 (2019) 712-721.

29 . Xia D.H., Song S., Qin Z., Hu W., Behnamian Y.: Electrochemical probes and sensors designed for time-dependent atmospheric corrosion monitoring: fundamentals, progress, and challenges. Journal of The Electrochemical Society 167(3) (2020) 037513.

30 . Morcillo M., Díaz I., Cano H., Chico B., De la Fuente D.: Atmospheric corrosion of weathering steels. Overview for engineers. Part I: Basic concepts. Construction and Building Materials 213 (2019) 723-737.

31 . Li X., Wang X., Wang L., Sun Y., Zhang B., Li H., ..., Hou B.: Corrosion behavior of Q235 steel in atmospheres containing $\mathrm{SO}_{2}$ and $\mathrm{NaCl}$. Journal of Materials Engineering and Performance 28(4) (2019) 2327-2334.

32 . Łatka L., Chicot D., Cattini A., Pawłowski L., Ambroziak A.: Modeling of elastic modulus and hardness determination by indentation of porous yttria stabilized zirconia coatings. Surface and Coatings Technology 220 (2013) 131-139.

33. Chmielewski T., Siwek P., Chmielewski M., Piątkowska A., Grabias A., Golański D.: Structure and selected properties of arc sprayed coatings containing in-situ fabricated $\mathrm{Fe}-\mathrm{Al}$ intermetallic phases. Metals 8(12) (2018) 1059.

34. Szala M., Walczak, M., Pasierbiewicz K., Kamiński, M.: Cavitation erosion and sliding wear mechanisms of AlTiN and TiAlN films deposited on stainless steel Substrate. Coatings 9(5) (2019) 340.

35. Winnicki M., Piwowarczyk T., Małachowska A.: General description of cold sprayed coatings formation and of their properties. Bulletin of the Polish Academy of Sciences. Technical Sciences 66(3) (2018) 301-310.

36. Deilami K., Kamruzzaman M., Liu Y.: Urban heat island effect: A systematic review of spatiotemporal factors, data, methods, and mitigation measures. International Journal of Applied Earth Observation and Geoinformation 67 (2018) 30-42.

37. Zhao C., Jensen J., Weng Q., Weaver R.: A geographically weighted regression analysis of the underlying factors related to the surface urban heat island phenomenon. Remote Sensing 10(9) (2018) 1428.

38. Theeuwes N.E., Steeneveld G.J., Ronda R.J., Holtslag A.A.: A diagnostic equation for the daily maximum urban heat island effect for cities in northwestern Europe. International Journal of Climatology 37(1) (2017) 443-454.

39. Guo N., Xu C., Du Y., Chen H., Fu Y., Feng J.: Influence of calcium fluoride on underwater wet welding process stability. Welding in the World 63(1) (2019) 107-116.

40 . Ma C., Wang Z., Behnamian Y., Gao Z., Wu Z., Qin Z., Xia D.H.: Measuring atmospheric corrosion with electrochemical noise: A review of contemporary methods. Measurement 138 (2019) 54-79. 